\title{
Heteronomia autonomii. Pole literackie i zagraniczna polityka kulturalna
}

Paweł Zajas 


\section{Heteronomia autonomii. Pole literackie i zagraniczna polityka kulturalna}

Paweł Zajas
Artykułpowstał

w ramach realizacji

projektu badawczego

nr 2014/13/B/HS2/00479,

sfinansowanego ze

środków Narodowego

Centrum Nauki.

TEKSTY DRUGIE 2017, NR 5, S. 28-47

DOI: $10.18318 /$ td.2017.5.3

1.

Relacje zachodzące między polem literackim a zagraniczną polityką kulturalną rzadko stanowią przedmiot systematycznej refleksji. W obszarze socjologii literatury zagraniczna polityka kulturalna wymieniana jest wprawdzie jako istotny element transferu literackiego', jednakże metodologiczne dezyderaty są w praktyce badawczej realizowane sporadycznie. Również w studiach, które w tytule podkreślają wagę aspektów społecznych i politycznych, heteronomiczne ramy "politycznego pola” omijane są szerokim łukiem.

Jednym z powodów braku zainteresowania ze strony literaturoznawców badaniami nad zagraniczną polityką kulturalną jest, jak można się domyślać, sformułowana

1 Por. W. Heinrichs Der Kulturbetrieb. Bildende Kunst, Musik, Literatur, Theater, Film, Transcript Verlag, Bielefeld 2006, s. 35-41; E. Fischer Übersetzungen auf dem Markt: Institutionen und Steuerungsfaktoren, w: Streifzüge im translatorischen Feld. Zur Soziologie der literarischen Übersetzung im deutschsprachigen Raum, Hrsg. von N. Bachleitner, M. Wolf, Lit Verlag, Wien 2010, s. 56.

\footnotetext{
Paweł Zajas profesor na Wydziale Anglistyki Uniwersytetu im. Adama Mickiewicza w Poznaniu oraz research fellow na University of Pretoria. W ostatnim czasie w obszarze jego zainteresowań znajdują się kwestie związane z transferem kultur/literatury oraz socjologią przekładu literackiego. Obecnie prowadzi badania w Deutsches Literaturarchiv Marbach jako stypendysta Fundacji im. Alexandra von Humboldta. Kontakt: zajas@wa.amu.edu.pl
} 
przez Pierre'a Bourdieu i wciąż reprodukowana w literaturze przedmiotu teza dotycząca opozycji „pola literackiego" $\mathrm{i}$ „pola władzy” jako przestrzeni „stosunków siły między podmiotami i instytucjami"2. W świetle tak spolaryzowanej perspektywy „władza heteronomiczna może występować w samym łonie pola [literackiego], wówczas jednak pozycja twórców jest „znacząco osłabiona przez tego swoistego konia trojańskiego"3. Trzeba jednak przypomnieć, że w owym jednoznacznie negatywnie zdefiniowanym i naszkicowanym za pomocą sugestywnej wojennej retoryki opisie mechaniki funkcjonowania pola kulturowego nie poddał Bourdieu dogłębnej analizie rozmaitych form heteronomii, nie dopuścił również do uznania niektórych z nich za czynniki pozytywne.

Niniejszy szkic stanowi prolegomenę projektu badawczego, który ma na celu częściowe wypełnienie owej luki. Na zasadzie laboratoryjnej próby proponuję przyjrzeć się bliżej wąskiemu, zarówno w sensie geograficznym, jak i czasowym, zbiorowi danych, który odsłania związki zachodnioniemieckiej zagranicznej polityki kulturalnej z polem literackim w okresie 1960-1970. Delimitacja materiału wymaga koniecznych wyjaśnień. O wyborze obiektu badań przesądza niewątpliwie towarzysząca mu doskonała sytuacja archiwalna. Akta bońskiego MSZ, dokumentujące proces planowania i implementacji zagranicznej polityki kulturalnej, nie zostały do chwili obecnej poddane kasacji i przechowywane są w Politisches Archiv des Auswärtigen Amts [Archiwum Politycznym MSZ] w Berlinie. Raporty roczne, wewnętrzne notatki, a także korespondencja centrali z ambasadami i przedstawicielstwami handlowymi, indywidualnymi pośrednikami, wydawnictwami i instytucjami pożytku publicznego, działającymi na zlecenie i finansowanymi przez niemiecki MSZ, umożliwiają sformułowanie odpowiedzi na pytanie, w jaki sposób ówczesne środowisko polityczne definiowało funkcję literatury. Działania instancji rządowych stanowią z oczywistych względów tylko część interesującego nas obrazu i należy je skonfrontować z perspektywą aktorów pola literackiego. I w tym przypadku dostępność niemieckich danych archiwalnych ma charakter zgoła unikalny. Archiwum Siegfrieda Unselda (Siegfried Unseld Archiv), które od 2009 roku zostało udostępnione badaczom w Deutsches Literaturarchiv w Marbach nad Neckarem i które zawiera zbiory takich oficyn jak Suhrkamp Verlag, Insel Verlag, Jüdischer Verlag i Deutscher Klassiker Verlag,

\footnotetext{
2 P. Bourdieu Reguły sztuki. Geneza i struktura pola literackiego, przeł. A. Zawadzki, Universitas, Kraków 2001, s. 329.

3 Tamże, s. 337.
} 
pozwala na pozyskanie informacji dotyczących reakcji pola wydawniczego na impulsy ze strony polityki.

Kombinacja dwóch typów zasobów stanowi jednocześnie propozycję metodologiczną, która umożliwia usytuowanie problematyki zagranicznej polityki kulturalnej w obrębie literaturoznawstwa. Gerhard Plumpe i Niels Werber wskazali w swoim tytułowo wieloznacznym (dającym się odczytać jako genetivus subjectivus/objectivus) studium Beobachtungen der Literatur na fakt, że począwszy od schyłku XVIII wieku, literatura „będąc zróżnicowanym fragmentem życia danego społeczeństwa stanowiła jednocześnie naturalne otoczenie innych systemów społecznych, które poddawały ją obserwacji i konceptualizacji zgodnie z własnymi oczekiwaniami”4. Autorzy pisali:

Owi zewnętrzni obserwatorzy to koegzystujące systemy społeczne, postrzegające literaturę nie w jej wyjątkowości, lecz, zgodnie z przyjętymi w ich ramach rozróżnieniami, jako towar, obiekt prawa, prowokację organów państwowych, medium niosące ze sobą ukojenie bądź prawdę, środek wychowawczy, przedmiot badań naukowych tudzież interpretacji. ${ }^{5}$

Tak sformułowany paradygmat badawczy autorzy określają za Niklasem Luhmannem mianem polikonteksturalnego, podkreślając tym samym, że postępująca dyferencjacja, powodowana mnożeniem granic w poszczególnych systemach, wymusza umiejętność posługiwania się wieloma kodami. Zgodnie z zasadami przyjętymi przez Plumpego i Werbera literatura nie stanowi monolitu, lecz winna być analizowana i opisywana jako

środowisko systemu prawa, gospodarki, estetyki filozoficznej, polityki, pedagogiki czy religii, celem zrekonstruowania koncepcji literatury funkcjonujących w poszczególnych systemach [...]. Jednocześnie należy stawiać pytania o rezonans owych zewnętrznych koncepcji we wnętrzu systemu literackiego. ${ }^{6}$

G. Plumpe, N. Werber Umwelten der Literatur, w: Beobachtungen der Literatur. Aspekte einer polykontexturalen Literaturwissenschaft, Hrsg. von G. Plumpe, N. Werber, Westdeutscher Verlag, Opladen 1995, s. 11.

5 G. Plumpe, N. Werber Vorbemerkungen, w: Beobachtungen der Literatur..., s. 7.

6 G. Plumpe, N. Werber Umwelten der Literatur..., s. 21-22. 
Zaproponowana przez niemieckich badaczy perspektywa polikonteksturalna zwraca naszą uwagę na wielość punktów obserwacyjnych, które mają następnie wpływ na różnorakie, funkcjonujące poniekąd obok siebie definicje literatury. Owa konstatacja wydaje się oczywista, niesie ona jednak ze sobą istotne konsekwencje dla lepszego zrozumienia dotychczas głównie negatywnie definiowanych czynników heteronomicznych, obecnych w polu literackim. W analizach ambiwalentnych relacji między polityką a kulturą wciąż jeszcze bowiem panuje przekonanie, że państwowy mecenat służy przede wszystkim osiągnięciu politycznych celów; owemu założeniu towarzyszy jednocześnie idealne wyobrażenie autonomicznego pola kulturowego, broniącego się przed wpływami z zewnątrz? . Wprowadzenie koniecznych niuansów do toczącej się dyskusji jest jednym z celów niniejszego szkicu.

\section{2.}

Dostępność danych uzasadnia poniekąd geograficzne usytuowanie próby badawczej oraz dobór metodologii. Co przemawia za zawężeniem badań do okresu 1960-1970? Dekada poprzedzająca politycznokulturalną ofensywę pierwszego rządu Willy'ego Brandta, która do publicznego dyskursu wprowadziła metafory „trzeciego filaru”/,trzeciej sceny" dyplomacji, jest w moim przekonaniu ciekawym historycznym momentem dla systematycznych dociekań nad różnymi formami relacji między autonomicznym polem literatury a polem polityki.

W tym właśnie czasie dochodzi do kilku sporów definicyjnych, zmieniających zarówno wewnętrzną strukturę, jak i granice literackiej i politycznej przestrzeni komunikacyjnej. Faza pierwsza odbywa się wewnątrz pola literackiego i dotyczy redefinicji funkcji autora i literatury. We Francji toczy go grupa twórców zrzeszonych w grupie Rue-Saint-Benoit, przede wszystkim Dionys Mascolo, Maurice Blanchot, Marguerite Duras i Robert Antelme. Przedmiotem sporu jest wojna w Algierii i polityka Charles'a de Gaulle'a, która znajduje wyraz w wystosowanym w 1960 roku „Manifeście 121”. Represje wobec sygnatariuszy przyczyniają się do powstania transnarodowej sieci, w ramach której dyskutowane są nowe formy krytyki. We Włoszech niepoślednią rolę odgrywają m.in. Italo Calvino i Elio Vittorini, a także czasopisma: „Quaderni Piacentini”, „Quindici”, ,Quaderni Rossi” i „Il Menabò”;

7 J. Adam Zwischen Selbstdarstellung und "Arbeit an der Weltvernunft": Wohin treibt die deutsche Auswärtige Kulturpolitik, "Aus Politik und Zeitgeschichte” 2016 no. 20-22, s. 34. 
w Niemczech ton nadają członkowie Grupy 47. Swoje działania postrzegają w kategoriach walki politycznej, a odgrywaną przez siebie rolę definiują poprzez kwestię odpowiedzialności społecznej pisarza ${ }^{8}$. Faza druga jest związana z zachodnioniemieckim czasopismem „Kursbuch”, założonym w 1965 roku przez Hansa Magnusa Enzensbergera, wydawanym pierwotnie w Suhrkamp Verlag i zaliczanym do najważniejszych organów opozycji pozaparlamentarnej i ruchu studenckiego. Na tym etapie spór wychodzi poza granice pola literackiego i przyczynia się do znaczących zmian w semantyce pojęcia „polityczności”. Zakwestionowane zostaje prawo aktorów pola politycznego do prawowitej wykładni działań zachodzących w społeczeństwie. Dostępne analizy ówczesnych wystąpień ilustrują tendencje do wykluczenia zawodowych polityków z przestrzeni "polityczności” i zajmowania wakującej pozycji przez pisarzy, określających swoją nową rolę mianem nouvelle possibilite ${ }^{9}$. W końcu, fazę trzecią można opisać jako proces transnacjonalizacji działań podejmowanych przez poszczególnych aktorów pola w ramach wspólnej przestrzeni komunikacyjnej; debaty na temat funkcji literatury jednocześnie podważały fundamentalną, jak się wówczas wydawało, kategorię państwa narodowego i postulowały potrzebę wytworzenia communauté internationale ${ }^{\mathbf{1 0}}$.

U podłoża postępującej radykalizacji pola literackiego tkwiło, jak zaznaczam powyżej, idealistyczne wyobrażenie ekskluzji „zawodowej” polityki ze sfery „polityczności”, którą, za Jacques'em Rancière'em, można zdefiniować jako „konfigurację specyficznej przestrzeni, podziałem szczególnej sfery doświadczenia, przedmiotów traktowanych jako wspólne i istotnych dla podejmowania wspólnej decyzji, podmiotów uznanych i zdolnych do określenia tychże przedmiotów oraz argumentacji w swojej sprawie"11. Jednocześnie

8 R. Schmidt Die unmögliche Gemeinschaft. Maurice Blanchot, die Gruppe der Rue Saint-Benoît und die Idee einer internationalen Zeitschrift um 1960, Kadmos, Berlin 2009, s. 33-40.

H. Marmulla Poesie, Politik und das Politische in der literarischen Sprache der 196oer Jahre, w: Politik. Situationen eines Wortgebrauchs in Europa der Neuzeit, Hrsg. von W. Steinmetz, Campus, Frankfurt am Main, New York 2007, s. 479-497; M. Winock Das Jahrhundert der Intellektuellen, UVK, Konstanz, s. 639-650.

H. Marmulla Internationalisierung der Intellektuellen? Möglichkeiten und Grenzen einer "communauté internationale" nach dem Algierienkrieg, w: Zwischen den Fronten. Positionskämpfe europäischer Intellektueller im 20. Jahrhundert, Hrsg. von I. Gilcher-Holtey, Akademie, Berlin 2006, s. $170-200$.

11 J. Rancière Estetyka jako polityka, przeł. .). Kutyła, P. Mościcki, Wydawnictwo Krytyki Politycznej, Warszawa 2007, s. 24. 
klasyczne pole władzy uważnie obserwowało tego typu poczynania, a następnie podejmowało próby wykorzystania autonomicznych i antagonistycznych działań artystów/pisarzy do poprawy własnego wizerunku na arenie międzynarodowej. Za egzemplifikację zjawiska może posłużyć korespondencja bońskiego MSZ dotycząca finansowego wsparcia zagranicznych podróży Hansa Magnusa Enzensbergera.

Fakt, że w kręgu bońskich decydentów wybór padł na tego konkretnego aktora pola literackiego, nie był bynajmniej przypadkiem. Po pierwsze, Enzensberger w sposób najbardziej dobitny akcentował w swojej ówczesnej twórczości relację literatury i polityki; po drugie, wśród dominujących na scenie literackiej "antysystemowych" pisarzy jako jedyny posiadał własne czasopismo („Kursbuch”), stanowiące transnarodowe forum pokolenia rewolty 1968 roku; po trzecie, dysponował sporym zasobem kapitału symbolicznego (uznanie publiczności i krytyki literackiej, liczne wyróżnienia ze strony instancji konsekrujących); w końcu, nie bez znaczenia było instytucjonalne powiązanie Enzenbergera z jednym z najważniejszych aktorów pola wydawniczego, oficyną Suhrkamp Verlag, z którą od 1957 roku był związany jako autor, w latach 1960-1962 jako redaktor wydawniczy, a następnie jako doradca, mający, co potwierdzają zgromadzone w SUA archiwalia, znaczący wpływ na jej linię programową).

Decyzja o wykorzystaniu kapitału społecznego Enzensbergera do celów zagranicznej polityki kulturalnej zapadła, co ciekawe, nie w odpowiedzialnym za tego typu działania pionie Wydziału Kultury MSZ, lecz szczebel wyżej: w podległym bezpośrednio ministrowi Federalnym Urzędzie Prasowym. Została ona oparta na przekonaniu, że „pisarze zaliczani na podstawie różnych określeń do grona tzw. lewicowych intelektualistów mogą okazać się nadzwyczaj przydatni dla niemieckich relacji kulturalnych"12. Za pośrednictwem oddziałów Instytutu Goethego wspierano finansowo i logistycznie w latach 1965-1972 liczne zagraniczne pobyty Enzensbergera, m.in. w Argentynie, Brazylii, Holandii, Indiach, Australii, Turcji i Szwecji. Raporty przesyłane przez konsulaty i ambasady były w centrali studiowane z dużą uwagą, a odręczne podkreślenia na zachowanych dokumentach świadczą o wadze jaką przykładano do prezentowanych przez niego publicznie "prowokacyjnych", "nonkonformistycznych wypowiedzi na temat RFN"13 w kwestiach takich jak

\footnotetext{
12 Vortragsreise von Herrn Dr. Hans Magnus Enzensberger nach Argentinien, 22.12.1965, Zwischenarchiv 109638, Politisches Archiv des Auswärtigen Amsts (dalej cyt. jako PA AA).

13 Ambasada RFN w Rio de Janeiro do MSZ w Bonn, 28.10.1965, Zwischenarchiv 109638, PA AA.
} 
zjednoczenie i remilitaryzacja Niemiec, status Berlina Zachodniego, konflikt z państwami „bloku wschodniego", stosunki polityczne w sowieckiej strefie wpływów i hegemoniczny status USA. Krytyczna postawa Enzensbergera i udział MSZ w organizacji jego zagranicznych podróży nie uszły uwadze chadeckich członków Bundestagu, którzy w ramach poselskich interpelacji protestowali przeciwko tego typu wystąpieniom „narażającym na szwank autorytet państwa"14. Wydział Kultury MSZ odpowiadał:

Doświadczenie uczy, że w krajach wciąż jeszcze sceptycznie nastawionych do Niemiec z pozytywnym odbiorem spotykają się przede wszystkim wykłady tych niemieckich autorów o międzynarodowej reputacji, którzy krytykują politykę rządu federalnego, co stanowi żywy dowód na panującą u nas duchową tolerancję. ${ }^{15}$

Politycznokulturalna strategia konserwatywnego rządu Ludwiga Erharda (1965-1966), a następnie Kurta Georga Kissingera (1966-1969), promująca na zewnątrz nader progresywne treści, które kontrastowały z zachowawczą polityką wewnętrzną, miała konsekwentny charakter: z perspektywy Bonn wartość zagranicznych wystąpień Enzensbergera wzrastała wprost proporcjonalnie do nasilającego się stopnia politycznego radykalizmu pisarza. Po tym, jak krytyka amerykańskiej interwencji w Wietnamie skłoniła go z początkiem 1968 roku do spektakularnej rezygnacji z profesury gościnnej na Wesleyan University oraz do publikacji listu skierowanego do rektora tej uczelni na łamach „New York Review of Books”, MSZ za nader pożądane uznał sfinansowanie pobytu autora na australijskim Adelaide Festival of Arts w marcu 1968 roku. Ambasada w Canberze raportowała bońskiej centrali o "wizerunkowym sukcesie" związanym z faktem, że publiczne wystąpienia Enzensbergera stanowiły przykład „intelektualnej suwerenności” oraz „doskonałej promocji współczesnych Niemiec”. Z zadowoleniem cytowano wypowiedź członka komitetu festiwalowego:

Publiczność musiała wyciągnąć prosty wniosek, że państwo, które ma odwagę wspierać tego rodzaju niezależnego ducha, samo jest depozytariuszem znamienitych idei i pozbawione jakiegokolwiek strachu. Postę-

Deutscher Bundestag, 5. Wahlperiode, 13.4.1967, Bonn 1967, s. 4754. 
puje ono w duchu dawnej angielskiej liberalnej prasy, słynącej z gotowości publikowania i wspierania pisarzy o poglądach sprzecznych z ich własną linią programową. ${ }^{16}$

\section{3.}

Odsuwając w czasie formułowanie wniosków, należy wskazać na kolejny, trzeci powód delimitacji materiału, opartej zarówno na specyficznym doborze próby badawczej (połączenie danych pochodzących z zasobów niemieckich archiwów federalnych i literackich), jak i ograniczeniu zakresu rozważań do lat 1960-1970. W tym kontekście warto bowiem przyjrzeć się również związkom między zagraniczną polityką kulturalną a polem literackim w kontekście historiografii polsko-niemieckich kontaktów kulturowych.

Pomocnicza funkcja czynników heteronomicznych wzmiankowana jest zarówno w nielicznych rozprawach poruszających kwestię stosunków kulturalnych między Polską a Republiką Federalną Niemiec, jak i w pracach poświęconych politologicznym aspektom niemieckiej polityki zagranicznej wobec Europy Środkowo-Wschodniej; pomija się ją jednakże w opisie procesów transferu literackiego, zachodzących w drugiej połowie XX wieku. Za egzemplifikację tego typu postaw może posłużyć wnikliwe studium Hedwig Nosbers, w którym działaniu instytucji federalnych autorka przypisała jednak rolę co najwyżej incydentalną ${ }^{17}$. Inną sporną w moim przekonaniu kwestią jest interpretacja podpisanego 7 grudnia 1970 roku „Układu między PRL a RFN o podstawach normalizacji ich wzajemnych stosunków" w kategoriach swoistej cezury w dziejach polsko-niemieckich stosunków kulturalnych. Konsens panujący w tej sprawie oddaje opinia wyrażona przez Andreasa Lawaty'ego, zgodnie z którą przed rokiem 1970 możemy mówić co najwyżej o polsko-niemieckich stosunkach kulturalnych, ale już nie o świadomej polityce kulturalnej ${ }^{18}$.

16

17

18

Ambasada RFN w Canberze do MSZ w Bonn, 4.7.1968, Zwischenarchiv 109638, PAAA.

H. Nosbers Polnische Literatur in der Bundesrepublik Deutschland 1945/1949 bis 1990. Buchwissenschaftliche Aspekte, Harrassowitz Verlag, Wiesbaden 1999, s. 281.

A. Lawaty Die kulturellen Beziehungen zwischen der Bundesrepublik Deutschland und der Volksrepublik Polen bis 1975, in: Die Beziehungen zwischen der Bundesrepublik Deutschland und der Volksrepublik Polen bis zur Konferenz über Sicherheit und Zusammenarbeit in Europa (Helsinki 1975), Hrsg. von W. Jacobmeyer, Georg-Ecker-Institut für Internationale Schulbuchforschung, Braunschweig 1987, s. 180-181. 
Owa temporalna linia demarkacyjna znajduje przede wszystkim oparcie w tradycyjnym obrazie wzajemnych stosunków po zakończeniu II wojny światowej, zgodnie z którym uzyskanie w maju 1955 roku przez Niemcy Zachodnie zewnętrznej suwerenności miało uniemożliwić nawiązywanie kontaktów politycznokulturalnych między Warszawą a Bonn. Główny punkt zapalny z perspektywy zachodnioniemieckiej stanowiła kwestia granicy na Odrze i Nysie, a także sformułowana we wrześniu 1955 roku „doktryna Hallsteina", definiująca podjęcie stosunków dyplomatycznych z NRD przez państwa trzecie w kategoriach nieprzyjaznego aktu. Za przejściowy okres w historii powojennych relacji zwykło się uważać lata tzw. Wielkiej Koalicji (1966-1969). Kurt-Georg Kiesinger podjął wówczas pierwsze próby politycznego porozumienia z władzami PRL, które jednakże, w wyniku wewnątrzpartyjnych sporów, zakończyły się niepowodzeniem. W końcu wybory do Bundestagu we wrześniu 1969 roku miały okazać się przełomem dla zachodnioniemieckiej Ostpolitik, w tym również kulturalnych kontaktów z Polską.

U podłoża diagnozy Lawaty’ego leży nie tylko zarysowany powyżej utarty schemat Ostpolitik, ale również zwyczajowa periodyzacja całej zachodnioniemieckiej zagranicznej polityki kulturalnej. Zgodnie z oficjalną historiografią jej odbudowa w latach powojennych hołdowała przede wszystkim celom "ponownej integracji Niemiec do wspólnoty międzynarodowej" ${ }^{\text {. }}$. Podobnie jak w okresie Republiki Weimarskiej za właściwe środki poprawy narodowego image'u miało się uważać autoprezentację i kulturowy eksport, przez co „przekaz realistycznego, otwartego i przyszłościowego obrazu nowej niemieckiej demokracji i sposobu, w jaki radzi sobie ona z własną trudną przeszłością, został na wiele dziesięcioleci postawiony w centrum zadań dyplomacji kulturalnej"20. Zagraniczna polityka kulturalna RFN w okresie powojennym przedstawiana jest tym samym jako swoista droga jednokierunkowa: pas transmisyjny ignorujący interesy krajów partnerskich, przenoszący wybrane elementy własnej kultury za granicę ${ }^{21}$. Zmiana tego stanu rzeczy łączona jest

19 
z rokiem 1970, w którym mianowany na sekretarza stanu w bońskim MSZ socjolog Ralf Dahrendorf sformułował program „międzypaństwowej polityki społecznej”22. Podmiotami „współpracy kulturalnej i nawiązania kontaktów między grupami społecznymi" miały być odtąd autonomiczne i jednocześnie wspierane przez państwo organizacje $\mathrm{e}^{23}$. Program ten został następnie zapisany w opublikowanym w 1975 roku sprawozdaniu końcowym parlamentarnej komisji ds. zagranicznej polityki kulturalnej, a dwa lata później zatwierdzony w oficjalnym stanowisku rządu federalnego ${ }^{24}$. Zgodnie z obecnym stanem badań rok 1970 otwiera nowy rozdział w historii niemieckiej dyplomacji kulturalnej, która „nie pozostaje ograniczona do jednostronnego eksportu kulturowego, lecz jest otwarta na wymianę i partnerską współpracę"25. Wgląd w materiał archiwalny stawia pod znakiem zapytania przywoływaną cezurę, odnoszącą się zarówno do historiografii bilateralnej wymiany, jak i do całej niemieckiej zagranicznej polityki kulturalnej.

Formułowane w jej ramach pierwsze koncepcje programowe w odniesieniu do Polski pojawiały się w drugiej połowie lat 50. w kręgach socjaldemokratycznej opozycji parlamentarnej ${ }^{26}$. Zachowana korespondencja urzędowa nie tylko dowodzi aktywności polityków SPD, ale jednocześnie świadczy o doskonałej orientacji odpowiedzialnego za kulturę pionu bońskiego MSZ w temacie bilateralnych projektów, realizowanych w owym czasie przez podmioty prywatne i stowarzyszenia. Inicjatywy ze strony SPD nie trwały długo: do uchwalonego w 1959 roku tzw. programu godesberskiego, pieczętującego m.in. odejście socjaldemokracji od zasad marksizmu, wpisano również realizację modelu bipartisan foreign policy, zakładającego w tej kwestii pełną współpracę z rządem ${ }^{27}$. W obszarze kultury obowiązującą wykładnię stanowiło odtąd wewnętrzne rozporządzenie MSZ:

Wytyczne rządu federalnego odnośnie polityki wobec europejskich krajów bloku wschodniego wykluczają naszym zdaniem wszelkie rozważania dotyczące zawarcia obowiązującej w świetle prawa międzynarodowego

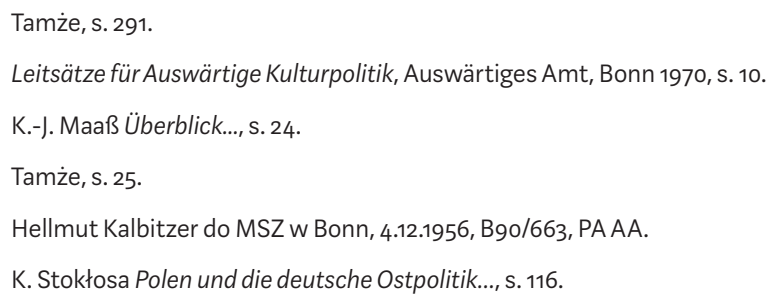


umowy o wymianie kulturalnej między RFN a PRL. W obecnej sytuacji próby ożywienia stosunków kulturalnych z Polską mogą odbywać się tylko i wyłącznie na płaszczyźnie prywatnej. ${ }^{28}$

Wbrew oficjalnym dyrektywom boński MSZ pełnił jednak nadal funkcję aktywnego aktora w niemiecko-polskim transferze literackim, wspierając za pośrednictwem instytucji pośredniczących rozmaite projekty osób prywatnych i wydawnictw, a także inicjując własne programy. Za pierwszą ilustrację politycznokulturowego outsourcingu może posłużyć finansowa pomoc dla wydawanego w latach 1956-1974 przez Hermanna Buddensiega czasopisma "Mickiewicz-Blätter”, jednoosobowej inicjatywy mającej na celu promocję literatury polskiej w Niemczech Zachodnich ${ }^{29}$. Zasięg pisma nie był duży, jednak w MSZ podjęto w roku 1959 decyzję o jego współfinansowaniu, które utrzymano aż do śmierci wydawcy w 1976 roku. W roli pośrednika wystąpiło dotowane przez Bonn i mające swoją siedzibę w Darmstadt stowarzyszenie Martin-Behaim-Gesellschaft, do zadań którego należała m.in. promocja niemieckiej kultury za granicą. Począwszy od 1961 roku, rząd niemiecki finansował także wyjazdy Buddensiega do Polski, a w 1963 roku współfinansował sporządzony przez niego przekład Mickiewiczowskiego Pana Tadeusza, opublikowany przez monachijskie wydawnictwo Eidos ${ }^{30}$. Ów gest interpretowano w specjalnie wydanym rozporządzeniu jako szczególny przejaw zainteresowania kulturą polską, przewyższający tego typu działania na terenie strefy

MSZ w Bonn, wydział 707 do wydziału 600, 29.01.1960, B9o/663, PA AA.

Informacje dotyczące sylwetki Buddensiega oraz tematycznej zawartości „Mickiewicz-Blätter" zawarte są w następujących publikacjach: O. Dobijanka-Witczakowa Hermann Buddensieg (1893-1976), w: „Nie będzie nigdy Niemiec Polakowi bratem”...?Z dziejów niemiecko-polskich zwiq̨zków kulturowych, red. M. Zybura, "Okis", Wrocław 1995, s. 225-235; G.B. Szewczyk Ein Freund Polens: Hermann Buddensieg, Übersetzer und Herausgeber der "Mickiewicz-Blätter", „Deutsch-polnisches Jahrbuch der Germanistik" 1993, s. 89-100; tejże Hermann Buddensieg, tłumacz, wydawca "Mickiewicz-Blätter", popularyzator literatury polskiej w Niemczech, w: Literatura polska w świecie. Zagadnienia recepcji i odbioru, red. R. Cudak, Gnome, Katowice 2006, s. 250-257; A. Jamiałkowska-Pabian Z dziejów literatury polskiej w Niemczech - Hermann Buddensieg, „AAta Universitatis Lodziensis. Folia Germanica" 2002 nr 3, s. 163-171.

\footnotetext{
Pozostaje kwestią sporną, w jakim stopniu Buddensieg był istotnie autorem przekładu. Podstawą jego wersji były starsze tłumaczenia i sporządzone przez innych przekłady filologiczne (H. Nosbers Polnische Literatur..., s. 219). Interesująca w tym kontekście jest również wyrażona w korespondencji z bońskim MSZ opinia Karla Dedeciusa, który bardzo krytycznie oceniał znajomość języków słowiańskich Buddensiega oraz jego kwalifikacje naukowe i literackie (MSZ w Bonn, notatka, 17.01.1967, Zwischenarchiv 109664, PA AA).
} 
sowieckiej, mający pozytywnie wpłynąć na prowadzone między RFN a PRL negocjacje handlowe ${ }^{31}$.

Kolejną egzemplifikacją heteronomicznego uwarunkowania polsko-niemieckiego transferu literackiego w okresie przed nawiązaniem oficjalnych stosunków dyplomatycznych jest działalność założonego w 1952 roku stowarzyszenia Inter Nationes. Formalnie podlegało ono zarówno Urzędowi Prasowemu jak i Ministerstwu Spraw Zagranicznych, a do jego zadań należało propagowanie pozytywnego wizerunku RFN za granicą ${ }^{32}$. Począwszy od lat 6o., Inter Nationes było jednocześnie półoficjalną jednostką pomocniczą MSZ do spraw współpracy kulturalnej z krajami „bloku wschodniego". Najlepiej udokumentowanym fragmentem tego obszaru aktywności jest działalność tzw. Besucherdienst, które współorganizowało i finansowało pobyt na terenie RFN „przedstawicieli profesji dziennikarskich oraz publicystycznych, a także osobistości istotnych z politycznego i kulturalnego punktu widzenia"33. Począwszy od roku 1965, regularnie rosła liczba wizyt z Czechosłowacji, Polski i Węgier, co Götz Fehr, urodzony w Pradze historyk sztuki i przewodniczący zarządu Inter Nationes, określał mianem „działań priorytetowych" ${ }^{\text {"34. }}$

Z racji faktu, że zaproszenie wystosowane przez agendę bońskiego MSZ wiązałoby się nie tylko z problemem uzyskania zezwolenia na wyjazd przez wschodnioeuropejskich gości, ale również byłoby niezgodne z obowiązującą w kontaktach z Europą Wschodnią doktryną Hallsteina, zdecydowano się na pracę „pod przykryciem”. Zaproszenia miały być wystosowywane nie bezpośrednio, lecz przez osoby trzecie: niemieckich naukowców, wydawców lub inne instytucje pośredniczące, przy czym Inter Nationes deklarował pełne pokrycie kosztów i pomoc w przygotowaniu programu podróży ${ }^{35}$. Wśród pośredników wytypowanych przez Inter Nationes znalazło się 
m.in. frankfurckie wydawnictwo Suhrkamp Verlag, które w drugiej połowie lat 6o. organizowało we współpracy z Inter Nationes wizyty publikujących w nim pisarzy wschodnioeuropejskich, w tym polskich: Zbigniewa Herberta, Wiesława Brudzińskiego, Kazimierza Brandysa, Marka Nowakowskiego i Juliana Stryjkowskiego ${ }^{36}$. Do dyspozycji wydawnictwa oddawano na czas wizyty lokalne biura stowarzyszenia w Monachium, Stuttgarcie, Frankfurcie, Bonn i Hamburgu, kładąc każdorazowo nacisk na poufny charakter źródła finansowania kosztów podróży i pobytu. Na podstawie dostępnej korespondencji trudno ustalić konkretne kryteria doboru gości, które, choć miały wyglądać na "suwerenną inicjatywę wydawnictwa"37, zapadały w ministerialnych gabinetach w Bonn. Najczęściej podnoszoną argumentacją była pozycja danego twórcy w systemie literackim/artystycznym kraju pochodzenia oraz jego "potencjalny wpływ na młodsze pokolenie" ${ }^{\text {38. }}$. Preferowano przy tym autorów, którzy nigdy wcześniej nie przebywali w RFN i których sytuacja finansowa uniemożliwiała samodzielne sfinansowanie tego typu podróży (na podstawie tego kryterium skreślono z listy kandydatów czeskiego poetę, dramaturga, plastyka i aktywistę politycznego Jiř́íego Kolářa $)^{39}$.

Ilustracja trzecia: kontakty między zachodnioniemieckim wydawnictwami a bońskim MSZ nie ograniczały się w latach 6o. do współpracy z Besucherdienst stowarzyszenia Inter Nationes. Przykładowo, w kwietniu i listopadzie 1967 roku kierownictwo Suhrkamp Verlag otrzymało zaproszenie do wzięcia udziału w organizowanym pod egidą MSZ seminarium dotyczącym „wymiany doświadczeń na temat relacji kulturalnych z państwami Europy Wschodniej"40, podczas których omawiano kwestię finansowego i logistycznego udziału rządu w transferze literatury polskiej do Niemiec oraz niemieckiej do Polski. Na impulsy płynące ze strony polityki

Korespondencja Inter Nationes z Suhrkamp Verlag, SUA: Suhrkamp/ozLektorate/Inter Nationes e.V., Deutsches Literaturarchiv Marbach (dalej cyt. jako DLA).

Götz Fehr do Waltera Boehlicha, 18.09.1967, SUA: Suhrkamp/ozLektorate/Inter Nationes e.V., DLA.

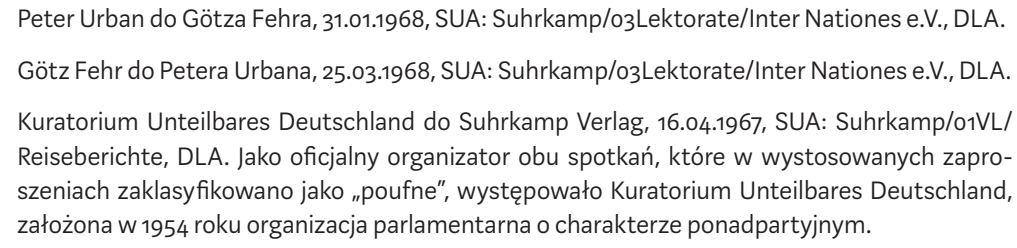
Reiseberichte, DLA. Jako oficjalny organizator obu spotkań, które w wystosowanych zaproszeniach zaklasyfikowano jako „poufne”, występowało Kuratorium Unteilbares Deutschland, założona w 1954 roku organizacja parlamentarna o charakterze ponadpartyjnym. 
wydawca, Siegfried Unseld, odpowiedział memoriałem dotyczącym planów „intensyfikacji wymiany kulturalnej z krajami socjalistycznymi”41. Oczekiwania ze strony wydawcy były wieloaspektowe. Dotyczyły m.in. lepszej koordynacji działalności Inter Nationes, mającej objąć również obustronną wymianę redaktorów i organizację wizyt niemieckich autorów w Europie Wschodniej, dofinansowania eksportu niemieckojęzycznych książek oraz subsydiowania udziału niemieckich wydawców na warszawskich Targach Książki.

Zaproponowane przez Unselda poszerzenie współpracy między działającymi na terenie RFN oficynami i MSZ spotkało się z pozytywną reakcją bońskich decydentów ${ }^{42}$. Przede wszystkim przystano na dofinansowanie prezentacji wydawnictw Suhrkamp i Hanser na warszawskich Targach Książki w czerwcu 1968 roku. Plany obejmowały finansowany przez MSZ kolportaż niemieckich przekładów poezji Zbigniewa Herberta i prozy Brunona Schulza, organizację przyjęcia dla polskich pisarzy, krytyków, wydawców i księgarzy, a w rolę gościa honorowego miał się wcielić Günther Grass. Choć prezentacja została w ostatniej chwili odwołana z powodu pogorszenia klimatu politycznego, spowodowanego zamieszkami marcowymi ${ }^{43}$, politycznokulturalny potencjał wspólnej inicjatywy wydawców i MSZ wykorzystano rok później w poszerzonym formacie na terenie Holandii, gdzie w październiku 1969 roku zorganizowano wystawę zatytułowaną "Osteuropäische Literatur in deutschen Übersetzungen“.U podłoża tej koncepcji tkwiły wcześniejsze pozytywne doświadczenia, związane z prezentacją zorganizowanej przez boński MSZ wystawy „Polonica in den Verlagen der Bundesrepublik 1946-1966”, przygotowanej z okazji Warszawskich Targów Książki w 1966 roku w polonijnych skupiskach w Chicago i Milwaukee ${ }^{44}$. Amsterdamska wystawa miała nie tylko szerszy zasięg (ok. 600 przekładów współczesnej beletrystyki jugosłowiańskiej, polskiej, rumuńskiej, węgierskiej, czechosłowackiej i radzieckiej), ale także jasno sprecyzowane cele: zniwelowanie antyniemieckich resentymentów holenderskiej inteligencji, uwypuklenie roli języka niemieckiego jako

41 P. Urban Zur Intensivierung des Kulturaustauschs mit den sozialistischen Ländern, 9.11.1967, SUA: Suhrkamp/01VL/Reiseberichte, DLA.

S. Unseld Reisebericht Bonn 10-13. November 1967, 14.11.1967, SUA: Suhrkamp/01VL/Reiseberichte, DLA. 
pomostu między kulturami Europy Wschodniej i Zachodniej, a także zaakcentowanie silnej roli RFN w obszarze transferu literackiego w odniesieniu do podobnych działań podejmowanych przez $\mathrm{NRD}^{45}$. Po amsterdamskiej premierze ekspozycję pokazano z początkiem 1970 roku w Belgii; planowana prezentacja w Szwajcarii, Francji i krajach skandynawskich została odwołana. Zmiana planów mogła być podyktowana postępującym procesem normalizacji stosunków między RFN a krajami bloku wschodniego. Kultura przestawała być ersatzem klasycznej dyplomacji.

Wszystkie trzy ilustracje uwypuklają istotną cechę ówczesnej zachodnioniemieckiej zagranicznej polityki kulturalnej: podczas gdy po roku 1970 współpraca między MSZ i instytucjami pośredniczącymi stała się przedmiotem licznych i doskonale znanych dokumentów/analiz, prezentowanych w kręgach rządowych i parlamentarnych, to przed tym okresem (dotyczy to w szczególności kontaktów z Europą Wschodnią) mamy wprawdzie również do czynienia z udanym politycznokulturalnym outsourcingiem, jednakże jego poufny charakter przyczynił się do powstania historiograficznej luki, której wypełnienie możliwe jest tylko i wyłącznie na podstawie materiału archiwalnego. „Uspołecznienie” niemieckiej zagranicznej polityki kulturalnej, łączone w literaturze z tezami Dahrendorfa, nie miało przed 1970 rokiem charakteru oficjalnej formuły, było jednakże bez wątpienia praktykowane. Również przywoływaną diagnozę Andreasa Lawaty'ego, według której przed cezurą roku 1970 możemy mówić co najwyżej o polsko-niemieckich stosunkach kulturalnych, ale już nie o polityce kulturalnej, można uznać za obowiązującą tylko wówczas, gdy wąską definicją zagranicznej polityki kulturalnej obejmiemy jedynie wiążące decyzje organów państwowych i umowy bilateralne ${ }^{46}$. Analizowane archiwalia stanowią jednakże dowód potwierdzający tezę, że boński MSZ już w latach 6o. był aktywnym aktorem coraz żywszego

Götz Fehr do MSZ w Bonn, 14.11.1968, Zwischenarchiv 109629, PA AA. Ostatni towarzyszący wystawie cel, akcentujący supremację Niemiec Zachodnich w politycznokulturalnym współzawodnictwie w obszarze transferu kulturowego między Europą Zachodnią i krajami "bloku wschodniego", nie pozostał niezauważony w Berlinie Wschodnim. Intencje Bonn zostały odnotowane w raporcie dotyczącym wystawy, sporządzonym przez Przedstawicielstwo NRD w Amsterdamie (Information über eine Ausstellung des Goethe-Instituts in den Niederlanden, 11.11.1969, MfAA C 270/73, PA AA).

W. Link Thesen über Mittlerorganisationen in den deutschen auswärtigen Kulturbeziehungen, w: Deutsche auswärtige Kulturpolitik seit 1871. Geschichte und Struktur. Referate und Diskussionen eines interdisziplinären Symposions, Hrsg. von K. Düwell, W. Link, Böhlau Verlag, Köln 1981, s. 263-264. 
wzajemnostronnego transferu literackiego między RFN a PRL, co pozwala z kolei na rewizję utartego obrazu ,jednokierunkowości” niemieckiej polityki kulturalnej przed 1970 rokiem.

\section{4.}

Zaprezentowana problematyka domaga się na zakończenie niezbędnego podsumowania, porządkującego rozważania dotyczące relacji między polem literatury a polem władzy. Fundamentalne pytanie, które należy postawić na koniec, brzmi: jeśli zagraniczna polityka kulturalna ma, jako nieodłączny element propagandy/dyplomacji, niezaprzeczalnie heteronomiczny charakter, jak wówczas powinniśmy definiować wykorzystywane w jej ramach autonomiczne formy literatury/sztuki? Czy przypisywana im autonomia jest fikcją, a przynajmniej staje się fikcją w momencie włączenia jej do mechanizmów polityki?

Klasyczne mechanizmy dystynkcji à la Bourdieu zakładają opozycyjną relację między heteronomicznym i autonomicznym biegunem pola kulturowego. Autonomia pola literackiego/artystycznego przestaje istnieć w momencie, w którym pisarze i artyści stają się podmiotami podporządkowanymi regułom obowiązującym w polu władzy ${ }^{47}$. Przyjmując tę logikę za obowiązującą, musielibyśmy zgodnie uznać, że finansowy udział czynników rządowych w projektach firmowanych przez aktorów pola literackiego znosi poniekąd automatycznie ich pozorną autonomię. W świetle danych archiwalnych mamy jednakże do czynienia z sytuacją paradoksalną: w żadnym z zaprezentowanych przypadków pisarze, wydawcy czy pośrednicy nie byli zmuszani do jakichkolwiek koncesji, które sprawiałyby, że ich działalność miała charakter heteronomiczny. De facto jedyną koncesją z ich strony była zgoda na podtrzymywanie iluzji całkowitej autonomii (brak publicznej informacji na temat wspólnego charakteru poszczególnych przedsięwzięć oraz politycznokulturalny outsourcing zacierający ślady bezpośredniej ingerencji ministerialnej centrali).

Ów paradoks jest oczywiście pozorny i daje się bez trudu wyjaśnić w ramach przyjętej za Plumpem i Werberem, a następnie dostosowanej do potrzeb prezentowanego materiału polikonteksturalnej ramy interpretacyjnej. Normatywnie pojmowana autonomia pola jest bowiem nie tylko koncepcją

47 P. Bourdieu The field of cultural production, or: The economic world reserved „PPoetics" 1983 No. 12, S. 319-320. 
formułowaną wewnątrz systemu literackiego, została ona również zaadoptowana przez politykę. W opublikowanym we wrześniu 1977 roku Stanowisku rządu federalnego podkreślano, że zamiarem bońskiego MSZ nie jest bynajmniej traktowanie kultury jako „służącej” zagranicznej polityki kulturalnej; zapewniano o zrozumieniu dla "długotrwałego, skomplikowanego i nader wrażliwego wzajemnego oddziaływania" obu systemów społecznych ${ }^{48}$. Ówczesna konstatacja koresponduje z wyrażoną w 2015 roku przez ówczesnego niemieckiego ministra spraw zagranicznych Franka-Waltera Steinmeiera definicją „apolitycznej przestrzeni”, w której kultura przygotowuje grunt pod „polityczne porozumienie, umożliwiające prewencję w zarządzaniu kryzysowym" ${ }^{49}$.

Tego typu zapewnienia formułowane w polu polityki należy interpretować w szerszym kontekście, wychodzącym poza podejrzenie doraźnej retoryki. Zdaniem Gisèle Sapiro „sytuacja poszczególnych narodowych pól literackich jest uzależniona od dwóch czynników: stopnia liberalizmu gospodarczego oraz stopnia liberalizmu politycznego" ${ }^{50}$. Szukając źródeł przekonania o powiązaniu autonomii sztuki z poziomem ekonomiczno-politycznej wolności, należy pewnie wskazać na Friedricha Schillera jako tego, który w opublikowanym w 1795 roku programie estetycznego wychowania człowieka explicite wyartykułował splot estetyki i polityki, wyciągając przy tym społeczne konsekwencje z romantycznego postulatu autonomii ${ }^{51}$.

Od tego czasu nowoczesna literatura jest literaturą autonomiczną. Sama ustanawia swoje prawa, które postrzega jako niezależne od zewnętrznych oczekiwań. Przywoływani na wstępie Gerhard Plumpe i Niels Werber postulowali odejście od tej ekskluzywnej definicji i podjęcie, w ramach proponowanego przez nich polikonteksturalnego paradygmatu, próby opisu literatury nie tylko w zgodzie z jej wewnętrznymi regułami, lecz także jako

Stellungnahme der Bundesregierung zu dem Bericht der Enquete-Kommission „Auswärtige Kulturpolitik"des Deutschen Bundestages, Drucksache 8/927, Bonn 1977, s. 5.

49 F. W. Steinmeier Weltvernunft! Wir müssen die soziale Kraft der Kultur stärken: Ein Beitrag zum Richtfest des Humboldt-Forums, "Die Zeit” 2015 no 24.

G. Sapiro The literary field between the state and the market, „Poetics” 2003 No. 31, s. 442.

F. Schiller Ueber die ästhetische Erziehung des Menschen, w: Schillers sämtliche Werke in einem Bande. Mit dem Portrait des Dichters, einer Faksimile seiner Handschrift und einem Anhang, Verlag der J. G. Cotta'schen Buchhandlung, Stuttgart-Tübingen 1834, s. 1195. Zob. G. Plumpe Epochen moderner Literatur. Ein systemtheoretischer Entwurf, Springer Fachmedien, Wiesbaden 1995, s. 78. 
istotnego elementu pozostałych systemów społecznych. Stawiane przez obu badaczy pytanie o „rezonans owych zewnętrznych koncepcji we wnętrzu systemu literackiego" można w tym miejscu odwrócić i zapytać o wpływ postulatu autonomii na pole polityki. Tok myślenia Schillera podjęty m.in. w socjologicznoliterackich rozważaniach Sapiro sugeruje, że autonomia pola, gwarantowana dostatecznym poziomem liberalizmu gospodarczego i politycznego, może jednocześnie odgrywać rolę papierka lakmusowego. Innymi słowy: publiczna prezentacja autonomicznych form literatury i sztuki implikuje należyte działanie liberalnych mechanizmów władzy, a tym samym (przynajmniej w systemach, w których liberalizm postrzegany jest jako cnota) posiada niezaprzeczalną wartość propagandową/politycznokulturalną.

Z punktu widzenia aparatu państwowego zaplanowana i koordynowana przez odpowiednie struktury proliferacja autonomicznych form kultury wydaje się więc celowa szczególnie w tych momentach historycznych, gdy państwo zmaga się na arenie międzynarodowej z problemem wizerunkowym. Przykładem tego typu zabiegów była propaganda kulturowa w latach 1914-1918, za pomocą której wilhelmińska Rzesza starała się zatrzeć obraz Niemiec jako agresora i zaprezentować się wobec neutralnej zagranicy jako na wskroś nowoczesne państwo, bardziej gustujące w awangardowym internacjonalizmie niż w konserwatywnych, narodowych formach mieszczańskiej sztuki. Propaganda kulturowa państw centralnych stanowiła tym samym swoistą niszę dla funkcjonowania autonomicznej sztuki w warunkach toczącego się konfliktu ${ }^{52}$. Ten sam wzorzec wpisany był w działania amerykańskiej Centralnej Agencji Wywiadowczej, które pod koniec lat 40. i w latach 50. XX wieku przyczyniały się do propagowania sztuki awangardowej w przemyśle literackim, kręgach akademickich, mediach czy licznych fundacjach. Ów „zimnowojenny modernizm" był specyficzną formą politycznej rekontekstualizacji eksperymentalnej awangardy, polegającej na zniwelowaniu jej radykalizmu, a następnie uczynieniu z niej nośnika „typowo amerykańskich" wartości, jak wolność i indywidualizm. Transfer tak zredefiniowanego modernizmu do Europy Zachodniej w latach 1946-1959 miał z jednej strony zapewnić sympatię zachodnioeuropejskich lewicowych elit, krytycznie nastawionych wobec płynącej z USA „Coca-kolonizacji”, z drugiej zaś uczynić modernistyczną sztukę

52 Mechanizm włączenia literatury i życia artystycznego do podejmowanych przez niemiecką Rzeszę działań propagandowych analizuję szczegółowo w monografii pt. Niemilknące muzy. Wydawcy pisarze, tłumacze i pośrednicy kulturowi na frontach Wielkiej Wojny 1914-1918, Wydawnictwo Naukowe UAM, Poznań 2016. 
(w jej zmodyfikowanym znaczeniu) atrakcyjną dla szerokiej mieszczańskiej publiczności ${ }^{53}$. W ten sposób, jak ujął to w 2007 roku Nathan Glazer, modernizm stał się kwestią „stylu” ${ }^{\text {"5 }}$.

Z tej właśnie perspektywy, przy zachowaniu należnych proporcji oraz uwagi wobec ewidentnych różnic, powinniśmy spojrzeć m.in. na przywoływany casus Enzensbergera. Aktorzy pola polityki, konfrontowani w drugiej połowie lat 6o. ze spektakularnym kryzysem legitymacji władzy oraz protestami rosnącej w siłę opozycji pozaparlamentarnej, postanowili wykorzystać społeczny i symboliczny kapitał autora, który jak żaden inny uosabiał ówczesną dialektykę „ "apolitycznie politycznej”55 literatury, mającej dodatkowo międzynarodowy zasięg. MSZ, finansując za pośrednictwem Instytutów Goethego zagraniczne pobyty pisarza oraz akceptując wyrażaną przez niego, niejednokrotnie w radykalny sposób, krytykę bońskiej polityki (prezentowaną najczęściej przed radykalnie lewicową publicznością), miał pełną świadomość politycznokulturalnej wartości tego typu działania.

Prezentowany materiał archiwalny stanowi częściowy dowód na to, że praktyki kulturowe i produkcja wydawnicza w zachodnioniemieckim polu literackim były wprawdzie powiązane z rządowymi subwencjami, nie oznaczało to jednakże ich podporządkowania politycznym dyrektywom. Zarówno pośrednicy indywidualni, jak i instytucjonalni działali z jednej strony autonomicznie, z drugiej zaś niejednokrotnie w ścisłej współpracy z bońskim MSZ i dzięki udzielanej przez ministerstwo pomocy finansowej. MSZ definiował transfer kultury z pozycji heteronomicznych, przypisując mu pozaliterackie kwalifikacje. Literatura oglądana z tej perspektywy staje się środkiem dyplomatycznego dialogu, pomostem porozumienia, pasem transmisyjnym ważkich społecznie tematów. Punkt widzenia prezentowany przez system polityki w niczym jednak nie ograniczał działań przedstawicieli pola

G. Barnhisel Cold War Modernists. Art, Literature \& American Cultural Diplomacy, Columbia University Press, New York 2015, s. 2, 4; por. F.S. Saunders Who Paid the Piper? The CIA and the Cultural Cold War, Granta Books, London 1999. Interesujący przegląd publikacji dotyczących transferu kulturowego w okresie zimnej wojny, zachodzącego w ramach/przy współudziale instytucji odpowiedzialnych za zagraniczną politykę kulturalną, można znaleźć w artykule Gilesa Scotta-Smitha oraz Joesa Segala Introduction, w: Divided Dreamworlds. The Cultural Cold War in East and West, ed. by P. Romijn, G. Scott-Smith, J. Segal, Amsterdam University Press, Amsterdam 2012, s. 3-5.

N. Glazer From a Cause to a Style: Modernists Architecture's Encounter with a American City, Princeton University Press, Pricenton, Oxford 2007. 
literackiego/wydawniczego. Jeśli zatwierdzimy powyższy wywód, wówczas stopienie porządków sztuki i polityki, interpretowane pozytywnie w kategoriach heteronomicznej autonomii, oznacza powrót literatury do gry sił zmieniających świat.

\section{Abstract}

\section{Paweł Zajas}

ADAM MICKIEWICZ UNIVERSITY (POZNAŃ)

UNIVERSITY OF PRETORIA

The Heteronomy of Autonomy: The Literary Field and Foreign Cultural Policy

This article introduces a research project on the relationship between literature and the mechanisms of foreign cultural policy in the context of Polish-German relations. Based on an analysis of records from the Polish Ministry of Foreign Affairs in Bonn from 1960 to 1970, Zajas asks how the political milieu at the time defined the function of culture. He juxtaposes the activities of government institutions with the perspective of agents in the literary field. For this group, data was obtained from the archive of the German publisher Siegfried Unseld, housed at the Deutsches Literaturarchiv Marbach, which was made available to researchers in 2009. This archive contains records from publishers such as Suhrkamp Verlag and Insel Verlag. The metatheoretical framework chosen to position the problem of foreign cultural policy within the realm of literary studies is the polycontextual framework proposed by Gerhard Plumpe and Niels Werber.

\section{Keywords}

polycontextual perspective, foreign cultural policy, the literary field, Siegfried Unseld's archive, Hans Magnus Enzensberger, Polish-German relations 